\title{
Treatment of overt and subclinical malabsorption in Haiti
}

\author{
F. A. KLIPSTEIN, I. M. SAMLOFF, G. SMARTH, AND E. A. SCHENK \\ From the Hôpital Albert Schweitzer, Deschapelles, Haiti, College of Physicians and Surgeons of Columbia \\ University, New York, and the University of Rochester School of Medicine and Dentistry, Rochester, New York, \\ USA
}

It is now recognized that abnormalities of small intestinal morphology and function in the tropics are found both in subjects with overt tropical sprue and in the asymptomatic indigenous population (Baker, Ignatius, Mathan, Vaish, and Chacko, 1962; Sprinz, Sribhibhadh, Gangarosa, Benyajati, Kundel, and Halstead, 1962; Lindenbaum, Alam, and Kent, 1966; Russell, Aziz, Ahmad, Kent, and Gangarosa, 1966; England and O'Brien, 1966). Previous studies in Haiti have indicated that such intestinal abnormalities are associated with a spectrum of clinical manifestations ranging from the asymptomatic state to overt tropical sprue (Klipstein, Samloff, and Schenk, 1966a). The aetiology of these intestinal changes in the asymptomatic subjects and their relationship to the lesion found in overt tropical sprue are uncertain. In some instances, protein malnutrition may be relevant to the aetiology of subclinical malabsorption (Mayoral, Tripathy, García, Klahr, Bolaños, and Ghitis, 1967); however, in those circumstances where protein malnutrition is absent, other factors must be invoked and it has been suggested that the intestinal lesion both in overt tropical sprue and in subclinical malabsorption may represent a reaction of the intestinal mucosa to similar, as yet unidentified, environmental factors (Klipstein, 1967).

Treatment of subjects with overt tropical sprue, using either folic acid or oral tetracycline, is known to result in improvement in intestinal morphology and absorptive capacity with the consequent correction of nutritional deficiencies (Sheehy, Baggs, Perez-Santiago, and Floch, 1962; Guerra, Wheby, and Bayless, 1965; Klipstein, Schenk, and Samloff, 1966b; O'Brien and England, 1966). To date, no studies have been reported concerning the results of similar treatment in subjects with subclinical malabsorption in the tropics. The present report describes the results of such therapy in 23 Haitians, eight of whom had overt and 15 of whom had subclinical malabsorption.

\section{SUBJECTS STUDIED}

The subjects studied, who came from rural areas of the Artibonite Valley, have been classified into the following groups: subjects with overt tropical sprue and subjects with subclinical malabsorption who either had evidence of protein deficiency or were asymptomatic. Individuals were selected for therapeutic studies from each of these groups according to the following criteria: (1) Eight (cases 1 to 8) were considered to have overt tropical sprue; all gave a history of diarrhoea (demonstrated to be unrelated to parasitic infestation), anorexia, and weight loss, and all were found to have florid megaloblastic erythropoiesis. (2) Seven (cases 9 to 15) were considered to have protein deficiency; all presented with pedal oedema and were found to have hypoalbuminaemia. All seven denied anorexia or recent weight loss; six denied diarrhoea and diarrhoea in the seventh (case 15) wasshown to be due to infestation with Endomoeba histolitica. Four of these subjects had mild megaloblastic changes. (3) Eight (cases 16 to 23 ) were entirely asymptomatic and were selected for study at random from the minor surgery clinic.

\section{METHODS}

Serum samples were obtained in the fasting state and maintained frozen in Haiti and during transit to New York City. Serum folate concentrations were assayed with Lactobacillus casei (Herbert, Baker, Frank, Pasher, Sobotka, and Wasserman, 1960); in this laboratory, normal subjects have serum levels between 7 and 20 $\mathrm{m} \mu \mathrm{g} / \mathrm{ml}$ and values of less than $5 \mathrm{~m} \mu \mathrm{g} / \mathrm{ml}$ are considered indicative of folate deficiency. Serum vitamin $B_{12}$ concentrations were assayed with Lactobacillus leichmanii (Spray, 1955); normal values in this laboratory range from 150 to $900 \mu \mu \mathrm{g} / \mathrm{ml}$. Intestinal biopsy specimens were obtained with a multiple purpose suction biopsy tube positioned under fluoroscopic control in the region of the ligament of Treitz and were subsequently fixed in $10 \%$ neutral buffered formalin. The techniques employed in the performance of the absorption studies have been recently described elsewhere (Klipstein et al, 1966a). Impaired renal function was excluded as a spurious cause of reduced excretion of test substances used in the absorption studies by the demonstration in every patient of a normal 
blood urea nitrogen concentration and, in 11 instances, corroborative serum xylose determinations.

Seventeen patients were treated initially with $5 \mathrm{mg}$ of folic acid daily; in addition, these subjects received $0.3 \mathrm{~g}$ of ferrous sulphate daily and $1,000 \mu \mathrm{g}$ of vitamin $B_{12}$ was administered parenterally at the onset of the study period. After periods of therapy ranging from four to 10 months, all subjects were re-evaluated and 10 were subsequently treated for two months with tetracycline, $250 \mathrm{mg}$ twice daily. Six patients were treated exclusively with tetracycline for four to six months; these subjects also received ferrous sulphate but were not given vitamin $B_{12}$. All patients received treatment on an outpatient basis during which time no attempt was made to supplement their dietary intake.

Determinations were considered indicative of improvement if the following criteria were met: weight gain of greater than $5 \mathrm{lb}$; an increase of haemoglobin concentration greater than $2.0 \mathrm{~g}$; an increase of serum albumin concentration greater than $1.0 \mathrm{~g} / 100 \mathrm{ml}$ or return to nor$\mathrm{mal}$; an increase of xylose excretion greater than $2.0 \mathrm{~g} /$ five hours or return to normal; return of ${ }^{60} \mathrm{CoB}_{12}$ absorption to normal. Jejunal biopsy changes were interpreted independently by two observers, both of whom were unaware of the therapeutic status of the patient. The criteria employed for categorizing the degree of villous abnormality have been described previously (Klipstein, 1964; Schenk, Samloff, and Klipstein, 1965). The severity of villous abnormalities was graded as follows: 0 , normal villi; $1+$, slight blunting and broadening; $2+$, moderate blunting and broadening; $3+$, marked blunting and broadening; $4+$, no villi seen.
RESULTS

PRETREATMENT OBSERVATIONS The results of laboratory investigations are presented in Tables I and II and the morphological abnormalities noted in pretreatment jejunal biopsy specimens are summarized in Fig. 1 and are illustrated in Figures 2 and 3.

Subjects with overt tropical sprue (cases 1 to 8) All eight patients had florid megaloblastic erythropoiesis; serum vitamin $B_{12}$ concentrations were subnormal in all eight and serum folate concentrations were subnormal in two. Serum albumin concentrations were subnormal in four and serum cholesterol concentrations were subnormal in seven. The absorption of xylose was subnormal in all eight patients and ${ }^{60} \mathrm{CoB}_{12}$ absorption was subnormal in all four patients tested. Jejunal biopsy showed moderate $(2+)$ villous abnormalities in three and marked (3+) changes (Fig. 2) in five.

Subjects with protein deficiency (cases 9 to 15) All seven patients were anaemic. Four patients (cases $10,12,13,14)$ had a reduced serum vitamin $B_{12}$ concentration and mild megaloblastic changes in the bone marrow; erythropoiesis was normoblastic in the other four subjects. Serum folate concentrations were normal in all seven subjects. Serum albumin and cholesterol concentrations and the absorption of xylose were subnormal in all seven patients and

TABLE I

RESPONSE TO TREATMENT WITH FOLIC ACID ${ }^{1}$

\begin{tabular}{|c|c|c|c|c|c|c|c|c|c|}
\hline \multirow[t]{2}{*}{$\begin{array}{l}\text { Case } \\
\text { No. }\end{array}$} & \multirow[t]{2}{*}{$\begin{array}{l}\text { Duration } \\
\text { of Therapy } \\
\text { (mth) }\end{array}$} & \multirow[t]{2}{*}{$\begin{array}{l}\text { Weight } \\
\text { Change } \\
(l b)\end{array}$} & $\begin{array}{l}\text { Haemoglobin } \\
(\mathrm{g} / 100 \mathrm{ml})\end{array}$ & $\begin{array}{l}\text { Serum } B_{12} \\
(\mu \mu g / m l)\end{array}$ & $\begin{array}{l}\text { Serum } \\
\text { Albumin } \\
(\mathrm{g} / 100 \mathrm{ml})\end{array}$ & $\begin{array}{l}\text { Serum } \\
\text { Cholesterol } \\
(\mathrm{mg} / 100 \mathrm{ml})\end{array}$ & $\begin{array}{l}\text { Xylose } \\
\text { Excretion } \\
(\mathrm{g} / 5 \mathrm{hr})\end{array}$ & \multirow[t]{2}{*}{$\begin{array}{l}{ }^{60} \mathrm{CoB}_{12} \\
\text { Excretion } \\
(\% \text { oral } \\
\text { dose) }\end{array}$} & \multirow[t]{2}{*}{$\begin{array}{l}\text { Degree of } \\
\text { Villous Abnor- } \\
\text { mality in } \\
\text { Jejunal Biopsy }\end{array}$} \\
\hline & & & $\begin{array}{l}\text { Normal Range } \\
13-15\end{array}$ & $150-900$ & $3 \cdot 5-4 \cdot 5$ & $150-275$ & $>5$ & & \\
\hline \multicolumn{10}{|c|}{ Tropical Sprue } \\
\hline \multicolumn{10}{|c|}{ Protein Deficient } \\
\hline $\begin{array}{r}9 \\
10 \\
11\end{array}$ & $\begin{array}{l}4 \\
3 \\
5\end{array}$ & $\begin{array}{l}-9 \\
+2 \\
+9\end{array}$ & $\begin{array}{r}7 \cdot 8-12 \cdot 8 \\
10 \cdot 7-14 \cdot 4 \\
8 \cdot 3-12 \cdot 2\end{array}$ & $\begin{array}{l}N \\
95-75 \\
165-50\end{array}$ & $\begin{array}{l}1 \cdot 9-3 \cdot 1 \\
3 \cdot 3-3 \cdot 4 \\
3 \cdot 0-3 \cdot 2\end{array}$ & $\begin{array}{c}63-133 \\
131-128 \\
100-118\end{array}$ & $\begin{array}{l}1 \cdot 1-4 \cdot 4 \\
3 \cdot 1-1 \cdot 3 \\
2 \cdot 8-2 \cdot 0\end{array}$ & $\begin{array}{l}6 \cdot 1-17 \cdot 1 \\
7 \cdot 8-\mathrm{NA} \\
6 \cdot 4-1 \cdot 8\end{array}$ & $\begin{array}{l}1+-2+ \\
1+-1+ \\
2+-3+\end{array}$ \\
\hline $\begin{array}{l}\text { Asyn } \\
16 \\
17 \\
18 \\
19 \\
20 \\
21 \\
22\end{array}$ & $\begin{array}{r}\text { atic } \\
4 \\
5 \\
3 \\
5 \\
6 \\
4 \\
4\end{array}$ & $\begin{array}{l}-11 \\
-4 \\
-14 \\
+22 \\
+4 \\
-4 \\
+2\end{array}$ & $\begin{array}{c}5 \cdot 0-14 \cdot 0 \\
10 \cdot 4-10 \cdot 0 \\
11 \cdot 5-9 \cdot 6 \\
6 \cdot 9-13 \cdot 1 \\
7 \cdot 9-13 \cdot 0 \\
10 \cdot 5-10 \cdot 6 \\
11 \cdot 3-10 \cdot 5\end{array}$ & $\begin{array}{l}\mathbf{N} \\
15-50 \\
N \\
N \\
N \\
N \\
N\end{array}$ & $\begin{array}{l}\mathbf{N} \\
\mathbf{N} \\
\mathbf{N} \\
\mathbf{N} \\
\mathbf{N} \\
\mathbf{N} \\
\mathbf{N}\end{array}$ & $\begin{array}{l}142-103 \\
\mathrm{~N} \\
112-150 \\
\mathrm{~N} \\
123-120 \\
130-150 \\
90-103\end{array}$ & $\begin{array}{l}3 \cdot 2-6 \cdot 1 \\
1 \cdot 8-1 \cdot 0 \\
1 \cdot 4-1 \cdot 1 \\
2 \cdot 2-4 \cdot 2 \\
3 \cdot 0-2 \cdot 5 \\
0 \cdot 7-2 \cdot 8 \\
5 \cdot 2-3 \cdot 3\end{array}$ & $\begin{array}{l}\mathrm{N} \\
1 \cdot 9-5 \cdot 7 \\
2 \cdot 3-2 \cdot 1 \\
1 \cdot 2-1 \cdot 7 \\
1 \cdot 3-20 \cdot 2 \\
2 \cdot 8-12 \cdot 2 \\
7 \cdot 0-20 \cdot 1\end{array}$ & $\begin{array}{l}3+-2+ \\
2+-2+ \\
2+-2+ \\
2+-2+ \\
3+-2+ \\
3+-1+ \\
2+-2+\end{array}$ \\
\hline
\end{tabular}

1Pretreatment values are followed by posttreatment values. Values with significant improvement are in italics. ${ }^{2} \mathrm{~N}$ indicates normal pretreatment value.

${ }^{3} \mathrm{NA}$ indicates value not determined before treatment. 
TABLE II

RESPONSE TO TREATMENT WITH TETRACYCLINE ${ }^{1}$

\begin{tabular}{|c|c|c|c|c|c|c|c|c|c|}
\hline \multirow[t]{2}{*}{$\begin{array}{l}\text { Case } \\
\text { No. }\end{array}$} & \multirow[t]{2}{*}{$\begin{array}{l}\text { Duration } \\
\text { of Therapy } \\
\text { (mth) }\end{array}$} & \multirow[t]{2}{*}{$\begin{array}{l}\text { Weight } \\
\text { Change (lb) }\end{array}$} & $\begin{array}{l}\text { Haemoglobin } \\
(\mathrm{g} / 100 \mathrm{ml})\end{array}$ & $\begin{array}{l}\text { Serum } B_{12} \\
(\mu \mu g / m l)\end{array}$ & $\begin{array}{l}\text { Serum } \\
\text { Albumin } \\
(\mathrm{g} / 100 \mathrm{ml})\end{array}$ & $\begin{array}{l}\text { Serum } \\
\text { Cholesterol } \\
(\mathrm{mg} / 100 \mathrm{ml})\end{array}$ & $\begin{array}{l}\text { Xylose } \\
\text { Excretion } \\
(\mathrm{g} / 5 \mathrm{hr})\end{array}$ & \multirow[t]{2}{*}{$\begin{array}{l}{ }^{60} \mathrm{CoB}_{12} \\
\text { Excretion } \\
(\% \text { oral } \\
\text { dose })\end{array}$} & \multirow[t]{2}{*}{$\begin{array}{l}\text { Degree of } \\
\text { Villous Abnor } \\
\text { mality on } \\
\text { Jejunal Biopsy }\end{array}$} \\
\hline & & & $\begin{array}{l}\text { Normal Range } \\
13-15\end{array}$ & $150-900$ & $3 \cdot 5-4 \cdot 5$ & $150-275$ & $>5$ & & \\
\hline \multicolumn{10}{|c|}{ Tropical Sprue } \\
\hline \multicolumn{10}{|c|}{ Protein Deficient } \\
\hline $\begin{array}{l}11^{4} \\
12 \\
13 \\
14 \\
15\end{array}$ & $\begin{array}{l}1 \\
5 \\
4 \\
5 \\
7\end{array}$ & $\begin{array}{l}+2 \\
+25 \\
+13 \\
+14 \\
+12\end{array}$ & $\begin{array}{c}12 \cdot 2-17 \cdot 1 \\
12 \cdot 5-14 \cdot 5 \\
10 \cdot 0-11 \cdot 4 \\
10 \cdot 1-12 \cdot 0 \\
8 \cdot 5-11 \cdot 3\end{array}$ & $\begin{array}{l}N \\
75-75 \\
35-25 \\
75-40 \\
N\end{array}$ & $\begin{array}{l}3 \cdot 2-3 \cdot 6 \\
3 \cdot 1-3 \cdot 0 \\
2 \cdot 6-2 \cdot 9 \\
1 \cdot 3-3 \cdot 1 \\
2 \cdot 3-3 \cdot 6\end{array}$ & $\begin{array}{c}118-167 \\
82-97 \\
92-107 \\
73-115 \\
118-150\end{array}$ & $\begin{array}{l}2 \cdot 0-2 \cdot 2 \\
2 \cdot 8-4 \cdot 0 \\
1 \cdot 4-1 \cdot 8 \\
0 \cdot 2-3 \cdot 7 \\
1 \cdot 0-5 \cdot 1\end{array}$ & $\begin{array}{l}1 \cdot 8-6 \cdot 1 \\
\text { NA-13.5 } \\
\text { NA-1.2 } \\
\text { NA-1.7 } \\
\text { NA-8.9 }\end{array}$ & $\begin{array}{l}3+-1+ \\
1+-1+ \\
2+-2+ \\
1+-1+ \\
3+-1+\end{array}$ \\
\hline \multicolumn{10}{|c|}{ Asymptomatic } \\
\hline $\begin{array}{l}20^{4} \\
21^{4} \\
22^{4} \\
23\end{array}$ & $\begin{array}{l}2 \\
2 \\
2 \\
5\end{array}$ & $\begin{array}{l}-4 \\
+2 \\
+5 \\
+1\end{array}$ & $\begin{array}{l}13 \cdot 0-11 \cdot 7 \\
10 \cdot 6-11 \cdot 3 \\
10 \cdot 5-12 \cdot 7 \\
12 \cdot 6-11 \cdot 9\end{array}$ & $\begin{array}{l}\mathbf{N} \\
\mathbf{N} \\
\mathbf{N} \\
\mathbf{N}\end{array}$ & $\begin{array}{l}\mathbf{N} \\
\mathbf{N} \\
\mathbf{N} \\
\mathbf{N}\end{array}$ & $\begin{array}{l}120-123 \\
N \\
103-132 \\
137-103\end{array}$ & $\begin{array}{l}2 \cdot 5-3 \cdot 4 \\
2 \cdot 8-4 \cdot 1 \\
3 \cdot 3-3 \cdot 6 \\
3 \cdot 6-5 \cdot 9\end{array}$ & $\begin{array}{l}N \\
N \\
N \\
N A-0.5\end{array}$ & $\begin{array}{l}2+-1+ \\
1+-1+ \\
2+-1+ \\
2+-2+\end{array}$ \\
\hline
\end{tabular}

${ }^{1}$ Pretreatment values are followed by posttreatment values. Values with significant improvement are in italics.

${ }^{2} \mathrm{~N}$ indicates normal pretreatment value.

${ }^{3} \mathrm{NA}$ indicates value not determined before treatment.

4Previously treated with folic acid.

${ }^{60} \mathrm{CoB}_{12}$ absorption was reduced slightly below normal in the three patients tested. Four patients had mild $(1+)$, two had moderate $(2+)$, and one had marked $(3+)$ villous abnormalities.

Asymptomatic subjects (cases 16-23) All eight patients were anaemic. One patient (case 17) had a subnormal serum vitamin $\mathbf{B}_{12}$ concentration and mild megaloblastic changes; the serum folate concentration was subnormal in two patients (cases 20 and 21), both of whom had normoblastic erythropoiesis. Serum albumin concentrations were normal in all eight subjects; serum cholesterol concentrations were subnormal in six patients; xylose absorption

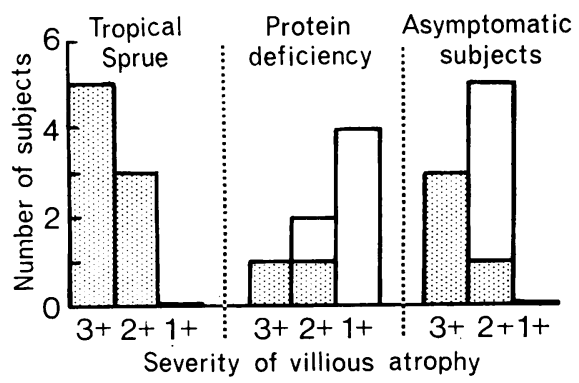

FIG. 1. Morphological abnormalities noted in pretreatment jejunal biopsies. Hatched areas indicate those biopsies in which morphological improvement occurred after therapy. was reduced in seven; and ${ }^{60} \mathrm{CoB}_{12}$ absorption was subnormal in all six patients tested. Five subjects had moderate $(2+)$ and three had marked $(3+)$ villous abnormalities (Fig. 3).

RESULTS OF TREATMENT The results of treatment with folic acid are shown in Table I and those following treatment with tetracycline are shown in Table II. The results of treatment with either folic acid, tetracycline, or both, are summarized in Figure 5.

Treatment with folic acid Seven patients with overt tropical sprue, three with protein deficiency, and seven asymptomatic subjects were treated with folic acid. Diarrhoea ceased within two weeks in all seven patients with tropical sprue. Two patients with tropical sprue, one with protein deficiency, and one asymptomatic subject, had a significant gain in weight. Oedema disappeared in all three patients with tropical sprue who had this abnormality before treatment and in all three patients with protein deficiency. A significant increase in the haemoglobin concentration occurred in five of the seven patients with tropical sprue, in all three patients with protein deficiency, and in three of the seven asymptomatic subjects. The serum vitamin $\mathbf{B}_{\mathbf{1 2}}$ concentration remained subnormal in six persons at the end of the therapeutic period. The concentration of serum 


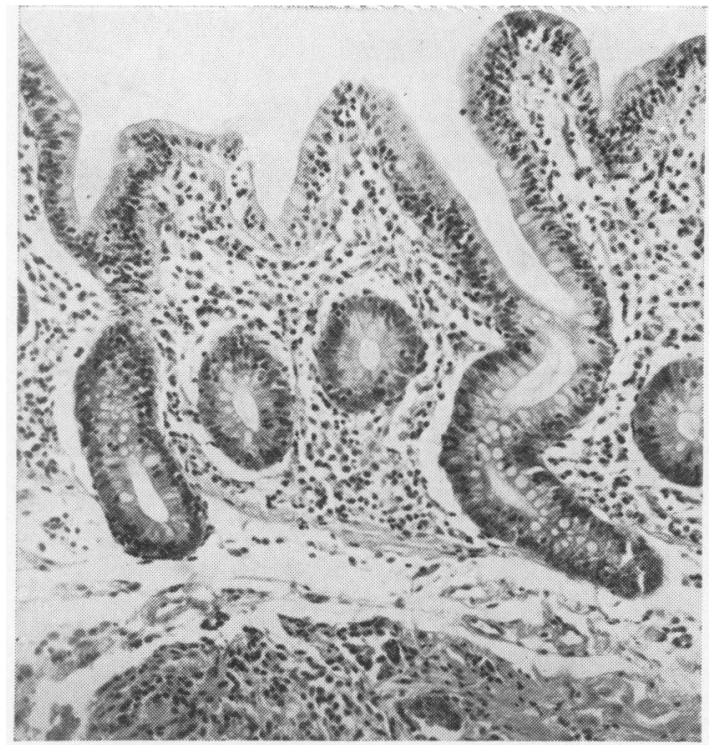

FIG. 2a。

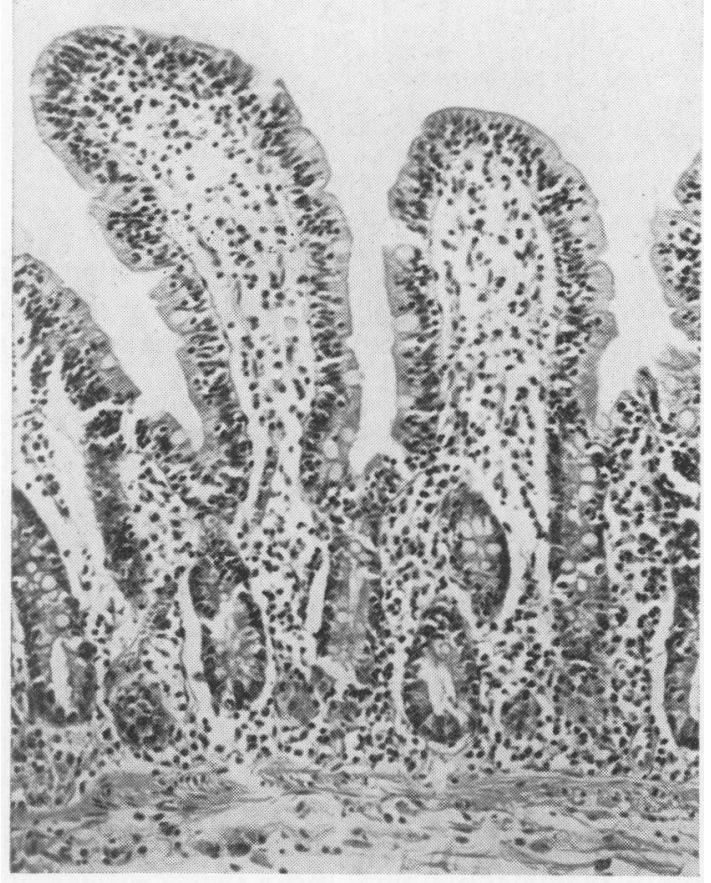

FJG. $2 b$.

FIG. 2. Jejunal biopsy in case 2 (overt tropical sprue). a, Pretreatment specimen shows shortened, broadened villi and a prominent infiltrate of chronic inflammatory cells within the lamina propria. The surface epithelium is pseudostratified. b, After treatment with folic acid, villous height is increased and the inflammatory cell infiltrate within the lamina propria is less prominent. Surface epithelial cells are now more columnar. (Haematoxylin and eosin $\times 40$.)

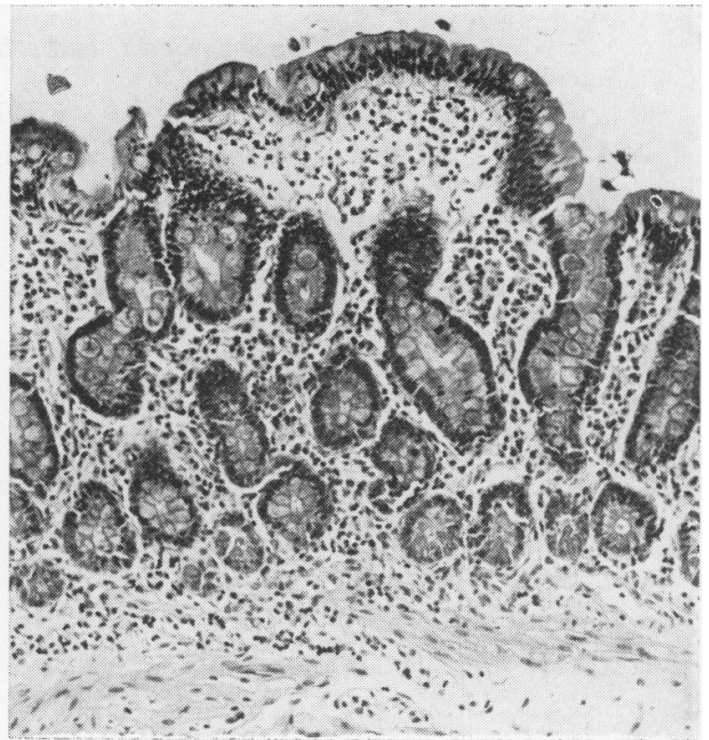

FIG. 3a.

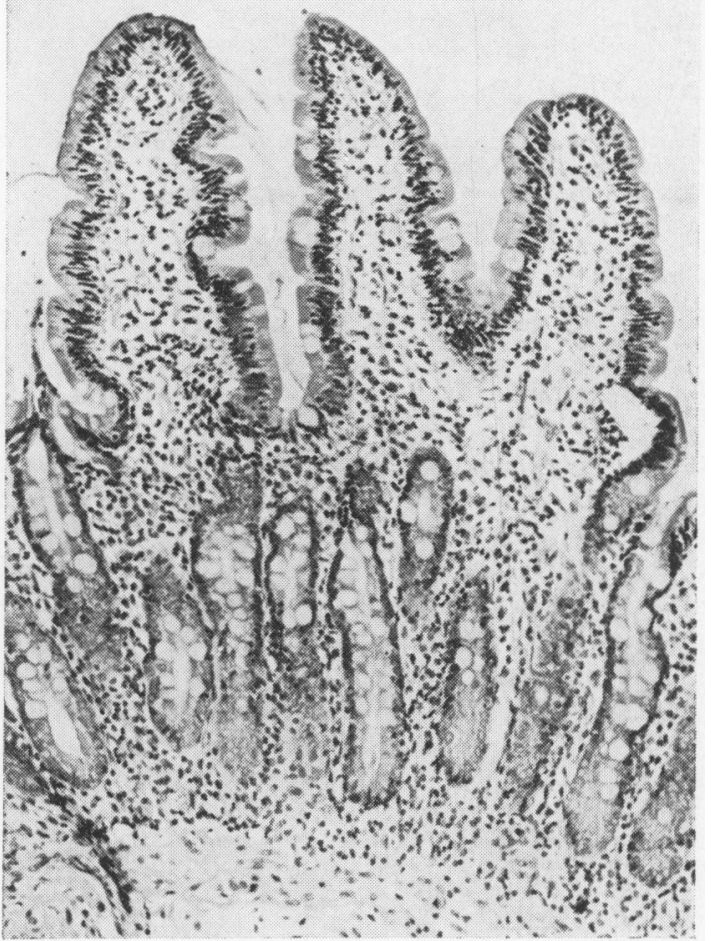

FIG. $3 b$.

FIG. 3. Jejunal biopsy in case 21 (asymptomatic subject). a, Pretreatment specimen shows nearly complete absence of villi. The surface epithelium consists of columnar cells but shows a marked inflammatory cell infiltrate. b, Specimen obtained after therapy with folic acid shows marked improvement in villous structure. There is a decrease in the number of inflammatory cells in the surface epithelium but the infiltrate within the lamina propria is only slightly reduced. (Haematoxylin and eosin $\times 40$.) 


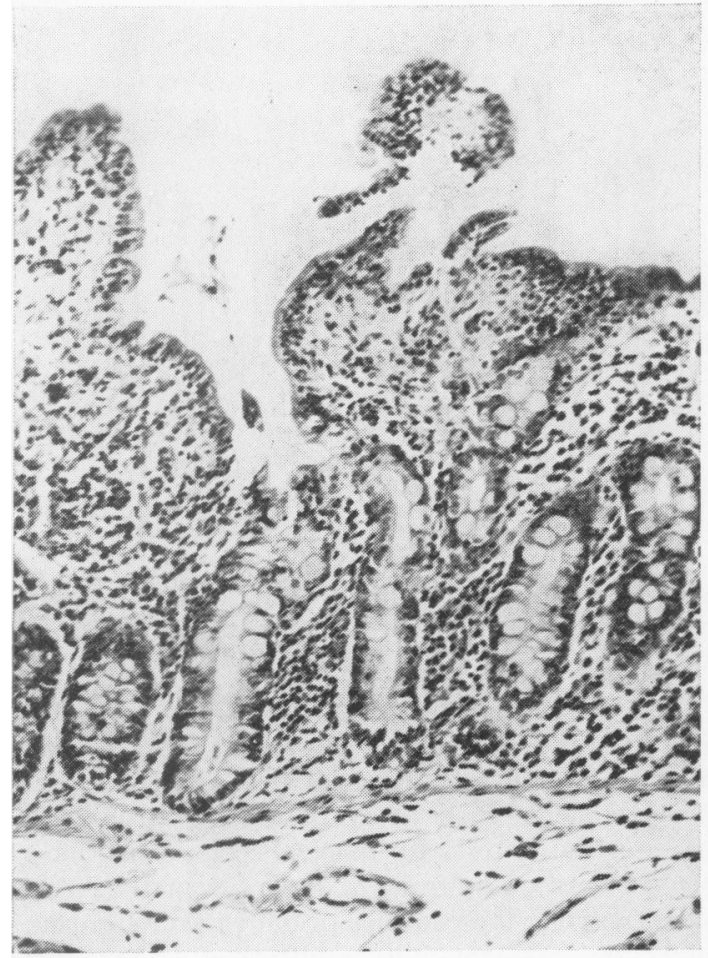

FIG. 4a.

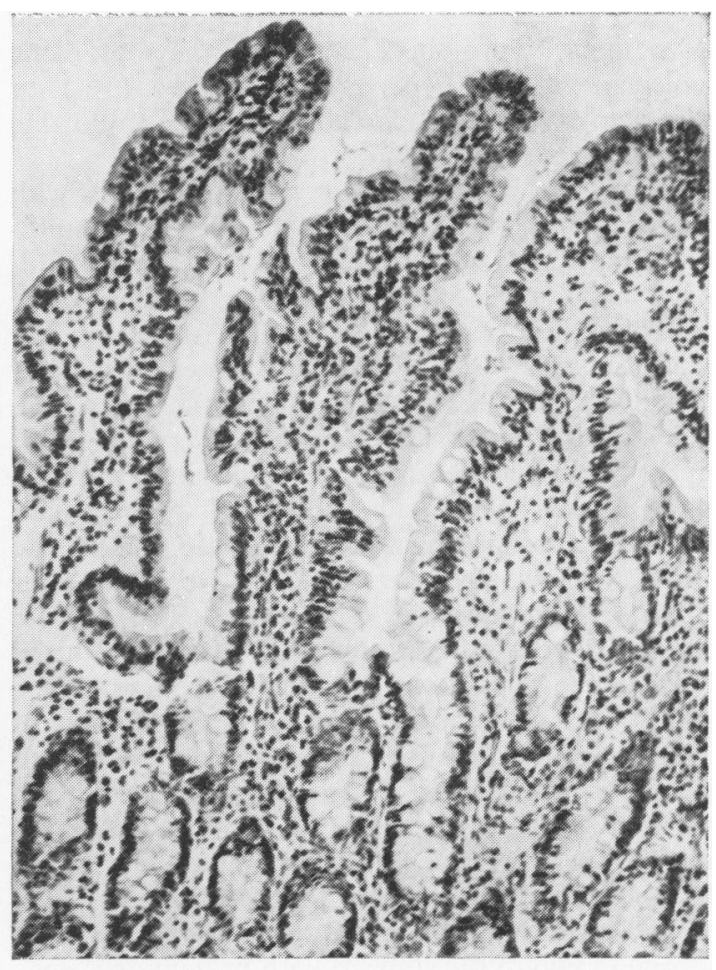

FIG. $4 \mathrm{~b}$.

FIG. 4. Jejunal biopsy in case 11 (protein deficiency). a, Specimen obtained after five months' treatment with folic acid shows persistence of severe villous abnormalities, a marked inflammatory cell infiltrate within the lamina propria, and pseudostratification of the surface epithelium. b, Specimen following treatment with tetracycline. Villi are now slender and finger-shaped. The surface epithelium shows only local pseudostratification, and the inflammatory cell infiltrate is reduced both within the surface epithelium and the lamina propria. (Haematoxylin and eosin $\times 40$.)

albumin rose in two of the five patients with tropical sprue who had subnormal pretreatment values and in one of the three patients with protein deficiency. The serum cholesterol concentration rose to normal in three patients with tropical sprue and in two asymptomatic subjects.

Xylose absorption increased in two patients with tropical sprue, in one patient with protein deficiency, and in three asymptomatic subjects. The absorption of ${ }^{60} \mathrm{CoB}_{12}$ remained subnormal in all seven patients with tropical sprue, but rose to normal in one patient with protein malnutrition and in three asymptomatic subjects. Jejunal morphology improved, with increased villous height and reduction in the inflammatory cell infiltration of the lamina propria, in six patients with tropical sprue, with reversal to mild $(1+)$ villous abnormalities in five of these six patients (Fig. 2b). There was also morphological improvement in three of the seven asymptomatic subjects with reversal to moderate $(2+)$ abnormalities in two and to mild $(1+)$ changes in one
(Fig. 3b). No change was evident in the biopsy appearance in the three subjects with protein deficiency, two of whom had mild $(1+)$ changes before treatment.

Treatment with tetracycline Six patients with tropical sprue (cases 2-7), one with protein deficiency (case 11), and three asymptomatic subjects (cases 20-22), who had received initial therapy with folic acid, were subsequently treated with tetracycline. Three of the patients with tropical sprue and one of the asymptomatic subjects gained weight. The concentration of haemoglobin rose in three subjects; the serum albumin concentration returned to normal in the subject with protein deficiency and the serum cholesterol concentration returned to normal in one of the patients with tropical sprue and in the subject with protein deficiency. Xylose absorption increased in two of the patients with tropical sprue and the absorption of ${ }^{60} \mathrm{CoB}_{12}$ became normal in another patient with tropical sprue. Jejunal morphology showed improvement, with reversal to mild $(1+)$ 
changes, in all five of the patients (two with tropical sprue, one with protein deficiency, two asymptomatic subjects) who had persistent, marked $(3+)$ or moderate $(2+)$ villous abnormalities following treatment with folic acid.

One patient with tropical sprue (case 8), four with protein deficiency (cases 12-15), and one asymptomatic subject (case 23 ) were treated exclusively with tetracycline and oral iron salts. Diarrhoea ceased in the one patient with tropical sprue and this patient as well as all four subjects with protein deficiency gained weight. The concentration of haemoglobin rose in four persons, although there was no increase in the serum concentration of vitamin $B_{12}$ in the four subjects who had subnormal pretreatment values. The serum albumin concentration rose in the patient with tropical sprue and in two of the four subjects with protein deficiency. The serum cholesterol concentration returned to within normal limits in the patient with tropical sprue and in one subject with protein deficiency. The absorption of xylose was increased in two of the four subjects with protein deficiency and in the single asymptomatic subject. The absorption of ${ }^{60} \mathrm{CoB}_{12}$ was not ascertained before treatment in these patients in order that they should not receive the vitamin at this time. Following treatment, the absorption of ${ }^{60} \mathrm{CoB}_{12}$ was normal in two of the subjects with protein deficiency and was subnormal in the one patient with tropical sprue, in two patients with protein deficiency, and in the single asymptomatic subject. Jejunal morphology was improved in the patient with tropical sprue and in one of the four subjects with protein deficiency (Fig. 4b). No change was apparent in the biopsy appearance in the one asymptomatic subject and in three subjects with protein deficiency, two of whom had mild $(1+)$ changes before therapy.

\section{DISCUSSION}

Pending the identification of its aetiology, tropical sprue remains an ill-defined entity whose variable manifestations are well recognized (Baker, 1957; Gardner, 1958; Klipstein, 1968). The identification of tropical sprue among the population of an area where intestinal morphological abnormalities are ubiquitous and malabsorption is common, such as in rural Haiti (Klipstein et al, 1966a; Klipstein, Samloff, Smarth, and Schenk, 1968), is thus often difficult. The purpose of the present study was to ascertain whether subjects with subclinical malabsorption would respond to therapy in a manner similar to patients with overt tropical sprue. To this end, 23 subjects who had varying clinical and laboratory manifestations of intestinal disease were selected from the outpatient clinic for treatment

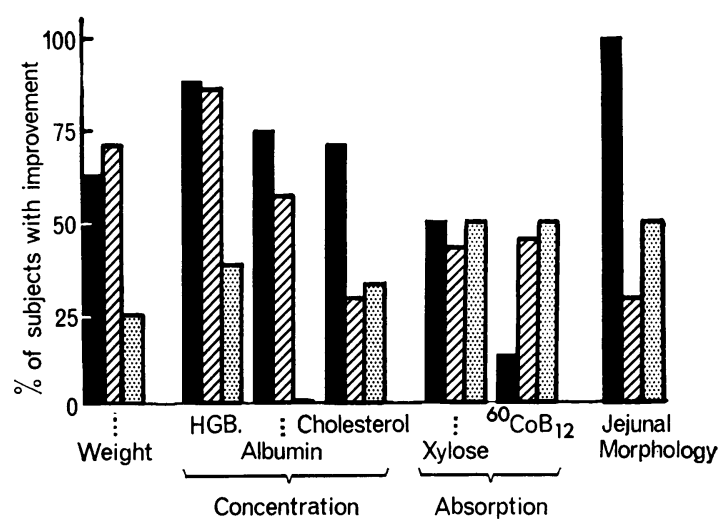

Tropical sprue Protein deficiency Asymptomatic

FIG. 5. Incidence of improved clinical and laboratory findings following treatment with folic acid, tetracycline, or both.

with folic acid and/or oral tetracycline in the absence of dietary supplements. Eight patients were considered to have overt tropical sprue since they met the criteria for tropical sprue which have been generally employed in the past in the West Indies, namely, the presence of diarrhoea, anorexia, weight loss, abnormalities of intestinal morphology and function, and a florid megaloblastic anaemia (Perez-Santiago and Butterworth, 1957; Gardner, 1958; Sheehy et al, 1962; Guerra et al, 1965). The other 15 patients treated had subclinical malabsorption in that none had diarrhoea or other overt manifestations of their gastrointestinal disease which would lead to the clinical diagnosis of tropical sprue. They have been divided into two groups based on the presence or absence of hypoalbuminaemia. The seven subjects referred to as protein deficient presented with pedal oedema and were found to have hypoalbuminaemia; four of these subjects had mild megaloblastic changes. In contrast, the eight asymptomatic subjects did not have oedema and had a normal serum albumin concentration.

It is now well established that treatment of overt tropical sprue with either folic acid or oral tetracycline commonly results in improvement in the intestinal lesion with amelioration of clinical symptoms and nutritional deficiencies (Sheehy and Perez-Santiago, 1961; Sheehy et al, 1962; Guerra et al, 1965; O'Brien and England, 1966). Such was the case in all eight patients with overt tropical sprue who were treated in the present study. Diarrhoea ceased in all, five gained weight, intestinal morphology improved in all eight, xylose absorption increased in four, and the concentration of haemoglobin, albumin, and cholesterol rose in a high 
proportion of cases. Similar improvement also occurred in some patients with protein deficiency and asymptomatic subjects following treatment. Weight gain occurred principally in the subjects with protein deficiency since these individuals were underweight before treatment; five of these seven subjects gained more than $10 \mathrm{lb}$ each. Of the 15 subjects with subclinical malabsorption (protein-deficient and asymptomatic subjects), jejunal morphology improved in six and xylose absorption improved in seven; the haemoglobin concentration rose in nine, the serum albumin concentration increased in four, and the serum cholesterol concentration returned to normal in four.

Swanson and her colleagues (Swanson, Wheby, and Bayless, 1966) have described a correlation between the severity of pretreatment morphological abnormalities and the response to therapy with folic acid in patients with overt tropical sprue. The limited number of subjects in the present study precludes any definite conclusion, but suggests that a similar circumstance may prevail in all subjects in the tropics irrespective of clinical manifestations. Thus, treatment resulted in morphological improvement in all nine subjects who had marked $(3+)$ abnormalities, in five of 10 subjects with moderate $(2+)$ changes but in none of the four cases with mild $(1+)$ changes. The mild changes were similar to those residual abnormalities which persisted in every patient following treatment both in the present study as well as in individuals with tropical sprue who have been treated by others (Guerra et al, 1965; England and O'Brien, 1966; Swanson et al, 1966). A correlation between improvement in jejunal morphology and nutritional status was apparent in the majority of cases in the present study. Morphological improvement was evident in eight of the 12 patients who gained weight, in six of the seven in whom the serum albumin concentration rose, and in eight of the nine in whom the serum cholesterol concentration returned to normal.

Intestinal absorptive function showed improvement in one-half of the 23 cases after treatment, but xylose absorption returned to within normal limits in only three instances and the absorption of ${ }^{60} \mathrm{CoB}_{12}$ was normal after treatment in only seven subjects. Others have had similar experience in the treatment of overt tropical sprue. Although therapy usually results in clinical improvement, impaired absorptive capacity has been found to persist in approximately one-half of patients treated either with folic acid (Perez-Santiago and Butterworth, 1957; Rodriguez-Molina, Cancio, and Asenjo, 1960; Sheehy et al, 1962) or with oral antibiotics when given over a short period of time (Sheehy and PerezSantiago, 1961). In some instances, the mucosal lesion has not healed completely, with return of absorptive capacity to normal until after treatment with folic acid for from one to two years (Sheehy et al, 1962; Sheehy, Cohen, Wallace, and Legters, 1965; O'Brien and England, 1966), and the extension of tetracycline therapy to six months has resulted in a significantly higher incidence of absorptive function returning to normal than short-term therapy (Guerra et al, 1965) accomplished. In the present study, the maximum period of treatment with folic acid was eight months and only three patients received tetracycline for six months. This suboptimal period of therapy may have, in part, been a factor in the persistence of malabsorption that was noted in a high proportion of cases.

The positive therapeutic effect of folic acid and tetracycline on the nutritional status and intestinal abnormality that was evident in some subjects with subclinical malabsorption implies that (1) malabsorption was of relevance in the aetiology of nutritional deficiencies in some of these subjects, and (2) that the intestinal abnormalities present in some subjects with subclinical malabsorption was related to the lesion of tropical sprue in that both respond favourably to the same form of therapy. At the same time, it must be recognized that intestinal improvement did not occur in all of the subjects with subclinical malabsorption and that the results of this study do not preclude the possibility that the intestinal lesion in other subjects may have been due to multiple aetiological factors. Inadequate dietary protein, for example, has been demonstrated to be of aetiological significance in the abnormalities of intestinal morphology and function which are commonly present in children with kwashiorkor (Stanfield, Hutt, and Tunnicliffe, 1965; Brunser, Reid, Mönckeberg, Maccioni, and Contreras, 1966) and implicated as a possible factor in similar lesions in adults (Zubirán, 1961; Mayoral et al, 1967). Sebrell and his co-workers (Sebrell, Smith, Severinghaus, Delva, Reid, Olcott, Bernadotte, Fougere, Barron, Nicolas, King, Brinkman, and French, 1959) have documented the fact that the dietary intake of the rural population of Haiti is suboptimal and all seven patients in the protein deficiency category in the present study related that their intake of protein was markedly reduced. Further therapeutic studies concerned with the effect of protein repletion without vitamin therapy in such subjects will be necessary to elucidate whether protein malnutrition is of relevance in the aetiology of their intestinal abnormalities.

\section{SUMMARY}

Twenty-three residents of rural Haiti who were found to have malabsorption, which was associated 
with overt symptoms of intestinal disease in eight and was subclinical in 15 , have been treated with folic acid or tetracycline, or both. Treatment of eight patients with overt tropical sprue resulted in cessation of diarrhoea in all, weight gain in five, reversal of jejunal morphological abnormalities towards normal in all eight, and increased xylose absorption in four; the haemoglobin concentration rose in seven, the serum albumin rose in three, and the serum cholesterol concentration rose to normal in five. Similar therapy in 15 subjects with subclinical malabsorption, seven of whom had protein deficiency, resulted in weight gain in seven, improvement in jejunal morphology in six, and increased xylose absorption in seven; the haemoglobin concentration rose in nine, the serum albumin concentration rose in four, and the serum cholesterol concentration returned to normal in four.

The response of the intestinal lesion to therapy appeared to be related principally to the severity of the pretreatment morphological abnormality rather than to the presence or absence of overt manifestations of intestinal disease. Thus, treatment resulted in improvement in jejunal morphology in all nine subjects who had marked $(3+)$ and in five of 10 subjects who had moderate $(2+)$ morphological abnormalities but no change occurred in any of the four subjects who had mild $(1+)$ changes.

These observations indicate that the intestinal abnormalities observed in asymptomatic residents and in patients with protein deficiency in areas where tropical sprue is endemic are, in some instances at least, related to the lesion of tropical sprue in that both respond favourably to similar therapy.

The authors wish to thank Drs W. Larrimer Mellon, Jr, and Frank Lepreau for their cooperation, Drs J. K. Cunningham, W. Mead, R. Hollister, and F. Charles for assistance in performing the studies, Drs F. M. Phillips and R. R. Widmann of Lederle Laboratories for supplies of folic acid and tetracycline (Achromycin), Mrs Mae MacDonald for performing the protein determinations, Dr R. Ruiz for performing the microbiological determinations, and Mrs M. Lobel for secretarial assistance.

This work was supported in part by a grant from the Williams-Waterman Fund for the Combat of Dietary Diseases, New York, NY, and US Public Health Service research grants HE 10465 and CA 02332 from the National Cancer Institute.

Requests for reprints should be addressed to: Frederick A. Klipstein, MD, University of Rochester Medical Center, 260 Crittenden Blvd., Rochester, New York 14620.

\section{REFERENCES}

Baker, S. J. (1957). Idiopathic tropical steatorrhea. Ind. J. med. Sci., $11,687-703$.

__, Ignatius, M., Mathan, V. I., Vaish, S. K., and Chacko, C. C.
(1962). Intestinal biopsy in tropical sprue. In Intestinal Biopsy (Ciba Foundation Study Group No. 14), edited by G. E. W. Wolstenholme and M. P. Cameron, pp. 84-101. Churchill, London.

Brunser, O., Reid, A., Mönckeberg, F., Maccioni, A., and Contreras, I. (1966). Jejunal biopsies in infant malnutrition: with special reference to mitotic index. Pediatrics, 38, 605-612.

England, N. W. J., and O'Brien, W. (1966). Appearances of the jejunal mucosa in acute tropical sprue in Singapore. Gut, 7, 128-139.

Gardner, F. H. (1958). Tropical sprue. New Engl. J. Med., 258, 791-796; 835-842.

Guerra, R., Wheby, M. S., and Bayless, T. M. (1965). Long-term antibiotic therapy in tropical sprue. Ann. intern. Med., 63, 619-634.

Herbert, V., Baker, H., Frank, O., Pasher, I., Sobotka, H., and Wasserman, L. R. (1960). The measurement of folic acid activity in serum: a diagnostic aid in the differentiation of the megaloblastic anemias. Blood, 15, 228-235.

Klipstein, F. A. (1964). Tropical sprue in New York City. Gastroenterology, 47, 457-470.

(1967). Editorial note: Tropical sprue-an iceberg disease? Ann. intern. Med., 66, 622-623.

(1968). Tropical sprue. Gastroenterology, 54, 275-293.

_- Samloff, I. M., and Schenk, E. A. (1966a). Tropical sprue in Haiti. Ann. intern, Med., 64, 575-594.

- - - Smarth, G., and Schenk, E. A. (1968). Malabsorption and malnutrition in rural Haiti. Amer. J. clin. Nutr., 21, 1042-1052.

-, Schenk, E. A., and Samloff, I. M. (1966b). Folate repletion associated with oral tetracycline therapy in tropical sprue. Gastroenterology, 51, 317-322.

Lindenbaum, J., Alam, A. K. M. J., and Kent, T. H. (1966). Subclinical small-intestinal disease in East Pakistan. Brit. med. J., 2, 1616-1619.

Mayoral, L. G., Tripathy, K., García, F. T., Klahr, S., Bolaños, O., and Ghitis, J. (1967). Malabsorption in the tropics: a second look. I. The role of protein malnutrition. Amer. J. clin. Nutr., 20, 866-883.

O'Brien, W., and England, N. W. J. (1966). Military tropical sprue from South-East Asia. Brit. med. J., 2, 1157-1162.

Perez-Santiago, E., and Butterworth, C. E., Jr. (1957). Definition and diagnosis of sprue. Amer. J. dig. Dis., 2, 225-235.

Rodriguez-Molina, R., Cancio, M., and Asenjo, C. F. (1960). The effect of folic acid on the steatorrhea of tropical sprue and other tests for intestinal absorption. Amer. J. trop. Med. Hyg., 9, 308-314.

Russell, P. K., Aziz, M. A., Ahmad, N., Kent, T. H., and Gangarosa, E. J. (1966). Enteritis and gastritis in young asymptomatic Pakistani men. Amer. J. dig. Dis., 11, 296-306.

Schenk, E.A., Samloff, I. M., and Klipstein, F. A. (1965). Morphologic characteristics of jejunal biopsy in celiac disease and tropical sprue. Amer. J. Path., 47, 765-781.

Sebrell, W. H., Jr, Smith, S. C., Severinghaus, E. L., Delva, H. Reid, B. L., Olcott, H. S., Bernadotte, J., Fougere, W., Barron, G. P., Nicolas, G., King, K. W., Brinkman, G. L., and French, C. E. (1959). Appraisal of nutrition in Haiti. Amer. J. clin. Nutr., 7, 538-584.

Sheehy, T. W., Baggs, B., Perez-Santiago, E., and Floch, M. H. (1962). Prognosis of tropical sprue: a study of the effect of folic acid on the intestinal aspects of acute and chronic sprue. Ann. intern. Med., 57, 892-908.

-, Cohen, W. C., Wallace, D. K., and Legters, L. J. (1965) Tropical sprue in North Americans. J. Amer. med. Ass., 194, 1069-1076.

- and Perez-Santiago, E. (1961). Antibiotic therapy in tropical sprue. Gastroenterology, 41, 208-214.

Spray, G. H. (1955). An improved method for the rapid estimation of vitamin $B_{12}$ in serum. Clin. Sci., 14, 661-667.

Sprinz, H., Sribhibhadh, R., Gangarosa, E. J., Benyajati, C., Kundel, D., and Halstead, S. (1962). Biopsy of small bowel of Thai people with special reference to recovery from Asiatic cholera and to an intestinal malabsorption syndrome. Amer. J. clin. Path., 38, 43-51.

Stanfield, J. P., Hutt, M. S. R., and Tunnicliffe, R. (1965). Intestinal biopsy in kwashiorkor. Lancet, 2, 519-523.

Swanson, V. L., Wheby, M. S., and Bayless, T. M. (1966). Morphologic effects of folic acid and vitamin $B_{12}$ on the jejural lesion of tropical sprue. Amer. J. Path., 49, 167-191.

Zubirán, S. (1961). Nutritional aspects of gastrointestinal disease. Amer. J. dig. Dis., 6, 336-350. 